\title{
THE EFFECT OF HYDROTHERMAL CONDITIONS ON OATS YIELDS IN EAST-CENTRAL POLAND (1975-2005)
}

\author{
Elżbieta Radzka', Jolanta Jankowska', Maria Markowska²
}

1 Department of Agrometeorology and Agricultural Engineering, Siedlce University of Natural Sciences and Humanities, Prusa 14, 08-110 Siedlce, Poland, e-mail: elzbieta.radzka@uph.edu.pl

2 Department of Foreign Languages, Siedlce University of Natural Sciences and Humanities, Prusa 14, 08-110 Siedlce, Poland

Received: 2015.03.02

Accepted: 2015.06.02

Published: 2015.07.01

\begin{abstract}
The objective of the work was to evaluate the effect of hydrothermal conditions on oats yields produced in east-central Poland. Hydrothermal conditions were determined based on the Sielianinov's hydrothermal coefficient for nine IMGW (Institute of Meteorology and Water Management) stations located in the study area. The second data set consisted of oats yields compiled and published by the Main Statistical Office. Average yields as well as minimum and maximum yields were analysed. The relationship between oats yields and hydrothermal conditions was examined using a step-wise linear regression model. Correlation coefficients were negative in April and positive in June at all the stations. The relationships were confirmed by an analysis of regression equations. The regression equations also included coefficients for May and June which, however, were not statistically significant. Yield variation, described by regression equations of the dependence of oats yield on Sielianinov's hydrothermal coefficient value was accounted for from 19 (Siedlce, Biała Podlaska) to 50\% (Ostrołeka).
\end{abstract}

Keywords: hydrothermal coefficient, growing season, oats, yield, central-eastern Poland.

\section{INTRODUCTION AND OBJECTIVE}

Marked variation of precipitation - its amount, intensity and distribution throughout the growing season - is the main cause of variation in the yields of cereals [Żarski 2009, Gąsiorowska et al. 2011]. Crop plant yields, including oats, predominantly depend on weather conditions, agrotechnological practices and soil conditions. The factors cause substantial yield variation every year. The relationship between precipitation and oats yield has been studied by many authors [Bobrecka-Jamro 1999, Ścigalska 1999, Stupnicka et al. 1999, Michalski et al. 1999, Skowera 2000]. According to Trybała (1996), 200-250 mm during the growing season is an optimal precipitation sum for oats cultivated on light soils. Also, a qualitative and quantitative description of droughts is significant for yield forecasting as they can cause substantial economic loss [Kędziora 2003]. Scenarios of climatic change predict increasing threat of droughts occurring during the growing season. As the forecasted warming is taking place in Poland, yielding conditions for warmth-loving plants improve but they become worse for potato and spring crops [Górski et al. 2008]. Oats is a relatively undemanding crop in terms of temperature and makes a good use of increased precipitation [Sułek et al. 2001, Sułek and Leszczyńska 2004]. The crop is classified as a moderate and humid climate plant. It germinates at $2-3{ }^{\circ} \mathrm{C}$, tillers best at $6-12^{\circ} \mathrm{C}$, elongates the shoots at $12-16{ }^{\circ} \mathrm{C}$. The coefficient of transpiration for oats is quite high (approx. 500). Precipitation occurring before sowing is of particular importance as oats have a hard outer hull and so need much water to germinate. Best yields are associated with precipitation in July at the stem elongation stage [Leszczyńska 2002]. The objective of the work was to determine the effect of hydrothermal conditions on oats yields in east-central Poland. 


\section{MATERIALS AND METHODS}

Meteorological data for 1975-2005 was obtained from the Institute of Meteorology and Water Management in Warsaw. Observations were taken at nine synoptic and climatic stations which are located in Ostrołka, Szepietowo, Białowieża, Pułtusk, Legionowo, Siedlce, Biała Podlaska, Sobieszyn and Włodawa (Tabela 1). The stations were selected so as to represent different former provinces in the study area (administrative division before 1999) (Tabela 2). Hydrothermal conditions were assessed based on the Sielianinov's hydrothermal coefficient.

The second dataset consisted of oats yields produced over 1975-2005 and compiled by the Main Statistical Office (Yields and harvests of main agricultural crops in 1975-1977, Output of main agricultural and horticultural crops in 19781991, Output of main agricultural crops according to provinces and producer groups in 1992-2005).

The relationship between oats yields and the values of Sielianinov's hydrothermal coefficient was determined by calculating linear correlation coefficients and checking their significance at the significance level of $\alpha=0.05$. Also, the relationship was examined by multiple linear regression according to the following model:

$$
\mathrm{Y}=\mathrm{b}_{0}+\mathrm{b}_{1} \mathrm{x}_{1}+\mathrm{b}_{2} \mathrm{x}_{2}+\ldots+\mathrm{b}_{\mathrm{n}} \mathrm{x}_{\mathrm{n}}
$$

where: $\mathrm{Y}$ - dependent variable (yield),

$\mathrm{x}_{1}, \mathrm{x}_{2}, \ldots, \mathrm{x}_{\mathrm{n}}-$ explanatory variables,

$\mathrm{b}_{0}$ - free term,

$\mathrm{b}_{1}, \mathrm{~b}_{2}, \ldots, \mathrm{b}_{\mathrm{n}}-$ regression coefficients which represent the rate of change of dependent variable $(\mathrm{Y})$ if the independent variable $(\mathrm{x})$ increases by one unit, the remaining values being constant.

Table 1. Geographic coordinates of synoptic and climatic IMGW stations in east-central Poland

\begin{tabular}{|c|c|c|c|}
\hline \multirow{2}{*}{ Station } & \multicolumn{2}{|c|}{ Geographic coordinates } & \multirow{2}{*}{$\begin{array}{c}\mathrm{H}_{\mathrm{s}} \\
\mathrm{m} \text { a.s.I }\end{array}$} \\
\hline & $\varphi^{\circ}$ & $\lambda^{\circ}$ & \\
\hline Ostrołęka & $53^{\circ} 05^{\prime}$ & $21^{\circ} 34^{\prime}$ & 95 \\
\hline Białowieża & $52^{\circ} 42^{\prime}$ & $23^{\circ} 51^{\prime}$ & 164 \\
\hline Włodawa & $51^{\circ} 33^{\prime}$ & $23^{\circ} 32^{\prime}$ & 163 \\
\hline Szepietowo & $52^{\circ} 51^{\prime}$ & $22^{\circ} 33^{\prime}$ & 150 \\
\hline Legionowo & $52^{\circ} 24^{\prime}$ & $20^{\circ} 58^{\prime}$ & 93 \\
\hline Biała Podlaska & $52^{\circ} 02^{\prime}$ & $23^{\circ} 05^{\prime}$ & 133 \\
\hline Sobieszyn & $51^{\circ} 37^{\prime}$ & $22^{\circ} 09^{\prime}$ & 135 \\
\hline Pultusk & $52^{\circ} 44^{\prime}$ & $21^{\circ} 06^{\prime}$ & 95 \\
\hline Siedlce & $52^{\circ} 11^{\prime}$ & $22^{\circ} 16^{\prime}$ & 146 \\
\hline
\end{tabular}

Explanations: $\varphi^{\circ}-$ latitude, $\lambda^{\circ}-$ longitude, $\mathrm{H}_{\mathrm{s}}$ - elevation above sea level.
Table 2. Administrative division of east-central Poland including selected stations

\begin{tabular}{|l|c|c|}
\hline \multicolumn{1}{|c|}{ Station } & $\begin{array}{c}\text { Administrative } \\
\text { division (provinces) } \\
\text { in 1975-1998 }\end{array}$ & $\begin{array}{c}\text { Administrative } \\
\text { division (provinces) } \\
\text { in 1999-2005 }\end{array}$ \\
\hline Ostrołęka & ostrołęckie & mazowieckie \\
\hline Pułtusk & ciechanowskie & mazowieckie \\
\hline Legionowo & warszawskie & mazowieckie \\
\hline Siedlce & siedleckie & mazowieckie \\
\hline Szepietowo & łomżyńskie & podlaskie \\
\hline Białowieża & białostockie & podlaskie \\
\hline Biała Podlaska & bialskopodlaskie & lubelskie \\
\hline Sobieszyn & lubelskie & lubelskie \\
\hline Włodawa & chełmskie & lubelskie \\
\hline
\end{tabular}

Regression equations were obtained by means of step-wise regression procedure. In the linear models presented (equations describing yield) values of t-Student statistic (|temp. $\mid>$ t $\alpha$ ) indicate significance of estimated regression parameters. The coefficient of determination $\left(\mathrm{R}^{2}\right)$ was calculated for each equation.

\section{RESULTS AND DISCUSSION}

Crop husbandry needs information on hydrothermal conditions so it is important to examine them in view if water shortages occurring and increasing in Poland. The lowest values of hydrothermal coefficient $\mathrm{K}$ are obtained for westcentral and central Poland. In recent years, a decline (from 32.8 to $4.5 \%$ ) in the area of Poland where quite wet conditions prevail $(1.6<\mathrm{K} \leq 2.0)$ in the summer has been observed coupled with an increase (from 14.4 to $44.3 \%$ ) in the area with quite dry conditions $(1.0<\mathrm{K} \leq 1.3)$ [Skowera 2014]. Hydrothermal conditions in Poland vary from region to region. Average values of Sielianinov's hydrothermal coefficient during the growing season (April-September) in eastcentral Poland from 1971 to 2005 ranged from 1.38 to 1.46 [Radzka, 2014].

Figure 1 demonstrates a description of oats yields in individual former provinces (administrative division from 1975 to 1998) of east-central Poland in the study years.

The average oats yield produced in the study area from 1975 to 2005 was $23.4 \mathrm{dt} \cdot \mathrm{ha}^{-1}$, the maximum yield was $29.1 \mathrm{dt} \cdot \mathrm{ha}^{-1}$ (chełmskie) and the minimum yield was $14.6 \mathrm{dt} \cdot \mathrm{ha}^{-1}$ (ostrołęckie). In the study by Kołodziej and Kulig [2007] based on results of field experiments with oats cv Jawor in 


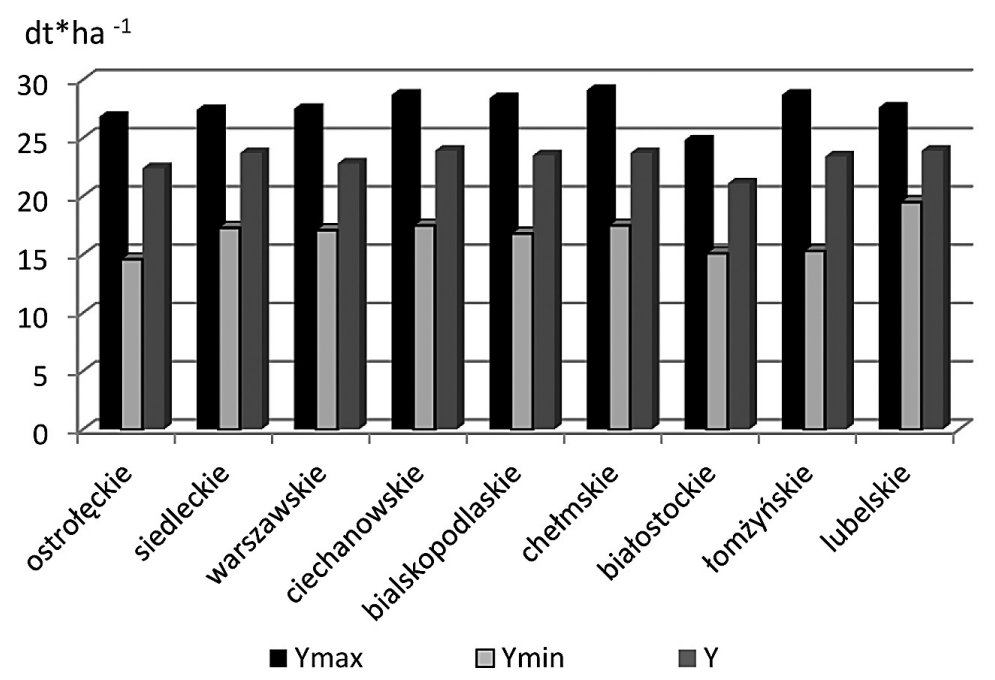

Figure 1. Values of average (Y), lowest (Ymin) and highest (Ymax) yields of oats in individual former provinces of east-central Poland in the years 1975-2005

1992-2003 at three COBORU (Research Centre for Cultivar Testing) stations, average oats yields were much higher and ranged from 37.1 to 84.6 dt $\cdot \mathrm{ha}^{-1}$. According to Budzyński and Krasowicz [2008], satisfactory levels of cereal yields depend on natural conditions, the right share of cereals in rotation and appropriate application of biological and agrotechnological progress.

Table 3 presents correlations between oats yields and hydrothermal conditions. Correlation coefficients were negative in all the stations in April but they were significant only for Białowieża, Szepietowo and Sobieszyn. Increasing intensity of droughts in June contributed to a significant decline in oats yields. In the remaining months of the growing season, there was no significant effect of hydrothermal conditions on oats yields. As a rule, high cereal yields are obtained when precipitation is low in winter and in April with higher rainfall during shoot elongation and flowering. If water shortages occur at these stages, and are accompanied by high air temperatures, yield structure gets worse [Bombik et al. 1999, Radzka et al. 2013]. Oat plants are prone to water deficit at initial growth stages and grain filling. Precipitation during the growing season has a significant effect on fat yield, as well [Pisulewska et al. 2011]. The relationship between oats yields and hydrothermal conditions in east-central Poland from 1975 to 2005 are presented in table 4.

Values of Sielianinov's coefficient for June entered all the regression equations. Regression coefficients for June were positive and significant at four stations (Ostrołęka, Legionowo, Biała Podlaska, Włodawa). A one unit increase in the coefficient value was followed by an increase in oats yield ranging from $1.5 \mathrm{dt} \cdot \mathrm{ha}^{-1}$ (Biała Podlaska) to $2.5 \mathrm{dt} \cdot \mathrm{ha}^{-1}$ (Legionowo). The regression coefficient for April entered four regression equations, being statistically significant in Białowieża

Table 3. Linear correlation coefficients between oats yields and the values of the Sielianinov's hydrothermal coefficient at individual stations of the study area

\begin{tabular}{|l|c|c|c|c|c|}
\hline \multicolumn{1}{|c|}{ Station/ Month } & April & May & June & July & August \\
\hline Włodawa & -0.268 & -0.148 & $0.451^{*}$ & 0.031 & -0.012 \\
\hline Pułtusk & -0.109 & 0.052 & 0.392 & 0.121 & -0.151 \\
\hline Siedlce & -0.291 & 0.092 & $0.399^{*}$ & 0.261 & -0.035 \\
\hline Białowieża & $-0.531^{*}$ & -0.287 & 0.211 & -0.292 & 0.031 \\
\hline Szepietowo & $-0.299^{*}$ & 0.031 & $0.512^{*}$ & 0.092 & -0.214 \\
\hline Biała Podlaska & -0.151 & -0.069 & $0.452^{*}$ & 0.031 & 0.021 \\
\hline Legionowo & $-0.298^{*}$ & 0.031 & $0.489^{*}$ & 0.159 & -0.091 \\
\hline Sobieszyn & $-0.598^{*}$ & 0.025 & 0.298 & 0.212 & -0.036 \\
\hline Ostrołęka & -0.311 & 0.244 & $0.611^{*}$ & 0.241 & 0.005 \\
\hline
\end{tabular}

$\mathrm{r}_{0.05}=0.36,{ }^{*}-$ siginificant at $\boldsymbol{\alpha}=0.05$ 
Table 4. The relationship between oats yields and values of Sielianinov's hydrothermal coefficient (AprilJune)

\begin{tabular}{|c|c|c|}
\hline Station & Regression equations & $R^{2} \times 100$ \\
\hline Pułtusk & $\begin{array}{l}\mathrm{Y}=23.930+1.236 \mathrm{VI}-0.804 \mathrm{IV} \\
\text { temp. } 14.496^{*} 1.835-1.792\end{array}$ & 26 \\
\hline Ostrołęka & $\begin{array}{l}\mathrm{Y}=17.453+1.754 \mathrm{VI}+1.137 \mathrm{~V}+0.711 \mathrm{VII}- \\
0.357 \mathrm{IV} \\
\text { temp. } 11.237^{*} 3.577^{*} 1.8341 .302 \\
-1.197\end{array}$ & 50 \\
\hline Legionowo & $\begin{array}{l}\mathrm{Y}=20.204+2.503 \mathrm{VI} \\
\text { temp. } 16.189^{*} 3.016^{*}\end{array}$ & 25 \\
\hline Białowieża & $\begin{array}{l}\mathrm{Y}=25.685-1.431 \mathrm{IV}-0.954 \mathrm{VII} \\
\text { temp. } 15.996^{*}-2.731^{*}-1.327\end{array}$ & 32 \\
\hline Biała Podl. & $\begin{array}{l}\mathrm{Y}=22.923+1.486 \mathrm{VI}-0.954 \mathrm{~V} \\
\text { temp. } 16.517^{*} 2.485^{*}-1.126\end{array}$ & 19 \\
\hline Włodawa & $\begin{array}{l}\mathrm{Y}=21.534+1.568 \mathrm{VI} \\
\text { temp. } 22.300^{*} 2.658^{*}\end{array}$ & 20 \\
\hline Szepietowo & $\begin{array}{l}\mathrm{Y}=22.245+1.203 \mathrm{VI}-0.795 \mathrm{IV} \\
\text { temp. } 14.338^{*} 1.967-1.752\end{array}$ & 25 \\
\hline Sobieszyn & $\begin{array}{l}\mathrm{Y}=23.402+0.549 \mathrm{VI}-0.79 \mathrm{IV}+0.594 \mathrm{VII} \\
\text { temp. } 17.535^{*} 1.008-2.539^{*} 1.192\end{array}$ & 22 \\
\hline Siedlce & $\begin{array}{l}\mathrm{Y}=22.923+1.486 \mathrm{VI}-0.954 \mathrm{~V} \\
\text { temp. } 16.517^{*} 2.485-1.126\end{array}$ & 19 \\
\hline
\end{tabular}

only. The hydrothermal conditions in the remaining months did not significantly affect oats yields. By contrast, Witkowicz et al. [2009] obtained higher yields in the growing season when precipitation was higher in April and May.

Variation in yield, described by means of equations of regression of oats yield on Sielianinov's hydrothermal coefficient, was accounted for from 19\% (Siedlce, Biała Podlaska) do 50\% (Ostrołęka). Analysis of linear correlation and methods of linear regression tend to be highly effective in forecasting oats grain yield and usable characteristics based on meteorological data [Michalski et al. 1999, Skowera and Kołodziej 2003]. By contrast, Dragańska et al. [2004] concluded that equations of weather-yield regression are of little use in assessing hydrothermal needs of oats.

\section{CONCLUSIONS}

1. Oats yields in east-central Poland were negatively correlated with values of Sielianinov's hydrothermal coefficient in April. However, in June correlation coefficients were positive and, at most stations, statistically significant, which confirms a negative effect of drought in June on oats yield.

2. Analysis of regression equations demonstrated that oats yields were most often affected by hydrothermal conditions in April and June.
A one unit increase in Sielianinov's coefficient was followed by an increase in oats yield which ranged from 1.5 to $2.5 \mathrm{dt} \cdot \mathrm{ha}^{-1}$. Although not significant, the values of hydrothermal coefficient for May and July entered the regression equations, too.

3. Variation in oats yield was from $16 \%$ (Puttusk) to $71 \%$ (Szepietowo) due to the values of hydrothermal coefficient.

\section{REFERENCES}

1. Bobrecka-Jamro D., Tobiasz-Salach R., Pilzło H. 1999. Ocena możliwości uprawy wczesnych rodów owsa w warunkach Beskidu Niskiego. Polskie Tow. Tech. Żywn. 1(18), 84-89.

2. Bombik A., Koc G., Starczewski J. 1999. Plonowanie podstawowych roślin uprawnych w zależności od przebiegu warunków meteorologicznych. Zesz. Nauk. AR w Szczecinie, 79, 20-37.

3. Budzyński W., Krasowicz S. 2008. Produkcja zbóż w Europie i w Polsce na przełomie XX i XXI wieku. Fragm. Agron. 1(97), 50-66.

4. Dragańska E., Kuchar L., Szwejkowski Z. 2004. Zastosowanie testu Cross Validation do weryfikacji modeli regresyjnych pogoda-plon na przykładzie pszenicy ozimej uprawianej $\mathrm{w}$ północno-wschodniej Polsce. Acta Sci. Pol., Agricultura 3(1), 29-36.

5. Gąsiorowska B., Cybulska A., Makarewicz A. 2011. Zawartość fosforu, potasu i wapnia w ziarnie wybranych odmian owsa siewnego. Medycyna Ogólna i Nauki o Zdrowiu, 17, 1, 17-22.

6. Górski T., Kozyra J., Doroszewski A. 2008. Field crop losses in Poland due to extreme weather conditions - case studies. In: S. Liszewski (Ed.) The Influence of Extreme Phenomena on the Natural Environment and Human Living Conditions; Łódzkie Towarzystwo Naukowe, 35-49.

7. Kędziora A. 2003. Ocena deficytów wodnych na obszarach rolniczych na przykładzie zlewni Wyskoć. In: Działalność naukowa PAN 15, 117-119.

8. Kołodziej J., Kulig B. 2007. Wpływ terminu i długości występowania faz rozwojowych na kształtowanie się plonu ziarna i wybranych cech owsa Acta Agrophysica, 9(2), 389-398.

9. Leszczyńska D. 2002. Uprawa owsa nieoplewionego - stan obecny i przyszłość. Pam. Puł. 130/II, 463-469.

10. Michalski T., Idziak R., Menzel L. 1999. Wpływ warunków pogodowych na plonowanie owsa. Polskie Tow. Techn. Żywn. 1(18), Kraków, 46-52.

11. Pisulewska E., Tobiasz-Salach R., Witkowicz R., Cieślik E., Bobrecka-Jamro B. 2011. Wpływ 
warunków siedliska na ilość i jakość lipidów w wybranych formach owsa. Żywność. Nauka. Technologia. Jakość 3(76), 66-77.

12. Radzka E. 2014. Hydrothermal characteristics of vegetation period in central-eastern Poland in years 1971-2005. Folia Pomeranae Universitatis Technologiae Stetinensis. Argicultura, Alimentaria, Piscaria et Zootechnica. 312(31), 133-142.

13. Radzka E., Gąsiorowska B., Koc G. 2013. Niedobory i nadmiary opadów atmosferycznych w okresie wegetacji zbóż jarych w rejonie Siedlec. Infrastr. i Ekolog. Ter. Wiejskich 2, 1, 147-154.

14. Skowera B. 2000. Wpływ elementów meteorologicznych na plonowanie roślin uprawnych w piętrach wysokościowych polskich Karpat Zachodnich. Acta. Agroph. 34, 169-180.

15. Skowera B. 2014. Zmiany warunków hydrotermicznych na obszarze Polski (1971-2010). Fragm. Agron. 31(2), 74-87.

16. Skowera B., Kołodziej J. 2003. Wpływ czynników termiczno-opadowych na plonowanie owsa w Kotlinie Orawsko-Nowotarskiej. Biuletyn IHAR, 229, 185-192.
17. Stupnicka-Rodzynkiewicz E. Lepiarczyk A., Łabza T., Hochół T., Pasek T. 1999. Plonowanie owsa w okolicach Krakowa w zależności od warunków pogodowych i sposobu uprawy roli. Polskie Tow. Techn. Żywn. 1(18), 186-152.

18. Sułek A., Leszczyńska D. 2004. Stan aktualny i perspektywy uprawy owsa w Polsce. Komunikat. Biuletyn Instytutu Hodowli i Aklimatyzacji Roślin 231.

19. Sułek A., Leszczyńska D., Zych J. 2001. Charakterystyka i technologia uprawy odmian owsa. Puławy - Radzików - Słupia Wielka.

20. Ścigalska B. 1999. Plonowanie odmian owsa w zależności od gęstości siewu w warunkach regionu południowo-wschodniego. Polskie Tow. Techn. Żywn. 1(18), 153-160.

21. Trybała M. 1996. Gospodarka wodna w rolnictwie. PWRiL, Warszawa.

22. Witkowicz R., Lepiarczyk A., Pisulewska E. 2009. Ocena plonowania różnych form owsa Fragm. Agron. 26(2), 165-175.

23. Żarski J. 2009. Efekty nawadniania roślin zbożowych w Polsce. Infrastr. i Ekolog. Ter. Wiejskich 6, 29-42. 